\title{
ANALYSIS OF HYDROTHERMAL CONDITIONS AND THEIR IMPACT ON EARLY POTATO YIELDS
}

\author{
Elżbiata Radzka', Katarzyna Rymuza', Tomasz Lenartowicz² \\ 1 University of Natural Sciences and Humanities in Siedlce, Prusa 14, 08-110 Siedlce, Poland, e-mail: elzbieta. \\ radzka@uph.edu.pl \\ 2 The Research Centre for Cultivar Testing in Słupia Wielka, 63-022 Słupia Wielka, Poland
}

Received: 2015.01.06

Accepted: 2015.02 .04

Published: 2015.04.01

\begin{abstract}
The work is based on data on monthly air temperatures, monthly sums of atmospheric precipitation and early potato yields in 2000-2013 obtained from seven COBORU (Research Centre for Cultivar Testing) stations situated in east-central Poland. Hydrothermal conditions during the growing season (April-July) of early potato were described by means of the Sielianinow's coefficient. The relationships between potato yields and the Sielianinow's hydrothermal coefficient of the growing season were examined using multiple regression equations generated by means of the step-wise regression procedure followed by polynomial regression procedure. The average Sielianinow's coefficient values ranged from 1.43 in April to 1.66 in May during the early potato growing season in east-central Poland. The applied statistical methods revealed that the hydrothermal factors impacted on early potato yields, particularly in the second stage of potato growth and development.
\end{abstract}

Keywords: Sielianinow's coefficient, growing season, east-central Poland, yield, early potato.

\section{INTRODUCTION}

Potato is one of the most widely cultivated crop plants [Chotkowski and Rembeza 2005]. It is grown predominantly on lighter soils, which makes potato yields dependent on evenly distributed precipitation. Importance of water has been stressed in many works published so far [Chmura 2001, Dzieżyc et al. 1987, Nowak 2001, Szutkowska and Lutomirska 2002]. The main meteorological factors shaping the living conditions of organisms are precipitation and thermal conditions. These two meteorological (and in multiyear - climatic) parameters are so important because they condition water circulation as well as mineral and organic substances circulation in the environment [Bochenek 2012].

The Sielianinow's hydrothermal coefficient is a useful tool for determining the water status of the environment [Kapuściński and Nowak 2003, Bartoszek and Banasiewicz 2007, Hutorowicz et al. 2008]. The relationship of crop plant develop- ment and yield with hydrothermal conditions is based on current or predicted temperature and atmospheric precipitation [Ziernicka-Wojtaszek 2009]. The list of crop plant cultivars encompasses many potato cultivars belonging to different maturity categories. The categories have got different development rhythm, time of growth to maturity and, first and foremost, different usability characteristics. As a result, they can be used in many ways in practice. Many cultivars cease to be registered on the Polish National List in a natural way and are replaced by new ones. Both new and already admitted cultivars respond differently to changeable cultivation conditions [Dmowski et al. 2004]. The already published works on potato precipitation needs are of help while assessing irrigation requirements of this crop at different times and in different areas of the country as potato is very responsive to improved moisture conditions [Mazurczyk et al. 2009, Nowak 2006, Rolbiecki et al 2009, Żarski 2011]. The effect of precipitation on early potato yields seems to 
be obvious but statistical methods of calculation used by many authors do not always confirm this [Biniak et al. 2007]. Useful as they are for analysing and determining quantitative relationships, the methods have got limitations, which stimulates researches to look for new ways of analysing the results [Kalbarczyk Kalbarczyk 2009].

The objective of this work was to describe hydrothermal conditions in east-central Poland and determine their effect on early potato yields.

\section{MATERIALS AND METHODS}

The work is based on average monthly air temperatures and monthly precipitation sums obtained from seven COBORU stations in eastcentral Poland in 2000-2013. The second data group consisted of average yields of early potato cultivars grown at seven stations included in the hydrothermal analysis. Values of Sielianinow's hydrothermal coefficient $(k)$, which is a measure of rainfall efficiency in a given month, were calculated for the growing season (April-July). Months were assigned to classes according to the following criterion:

- extremely dry (ed) $k<0.40$

- very dry (vd) $0.41<k<0.70$

- $\operatorname{dry}$ (d) $0.71<k<1.0$

- quite dry (qd) $1.01<k<1.30$

- optimum (o) $1.31<k<1.60$

- quite wet (qw) $1.61<k<2.0$

- wet (w) $2.01<k<2.5$

- very wet (ww) $2.51<k<3.0$

- extremely wet (ew) $k>3.01$ [Skowera and Puła 2004].

Spatial distribution of average monthly values of Sielianinow's coefficient in the study area are presented using isolines. The relationship between potato yields and Sielianinow's hydrothermal coefficient was examined by means of multiple regression equations. Multiple regression coefficients were obtained using the stepwise regression procedure. Moreover, to check the significance of regression coefficients, t-Student test values were calculated and determination coefficients were computed $\left(R^{2}\right)$. The determination coefficient is a measure of goodness of fit which explains what portion of the total variation of variable $Y$ is explained by linear regression on independent variables [Trętowski, Wójcik 1991]. In order to more fully describe the phenomenon, the potato growing season was divided into two pe- riods with individual months including the most important developmental stages of plants (Stage1: April-May and Stage2: June-July). Equations of multiple regression were used to construct models describing the relationship of potato yield with Sielianinow's coefficient in individual stages. Significance of regression coefficients was checked using t-Student test at $\mathrm{p} \leq 0.05$. All calculations were performed in Statistica 10.0.

\section{RESULTS AND DISCUSSION}

The transitional nature of Polish climate manifests itself in substantial variability of values of individual climate components, including air temperature and precipitation. Thus, it is important to examine hydrothermal conditions taking into accounts agricultural economy needs. Analysis of hydrothermal conditions demonstrated that, during the growing season, the average value of Sielianinow's coefficient in the study area ranged from 1.43 in April to 1.66 in May. Skowera [2014] analysed the hydrothermal conditions in Poland from 1971 to 2010 and noted that the average value of hydrothermal coefficient was the lowest in August $(k=1.3)$. Kalbarczyk [2003] claims that this value ranges from 1.29 to 1.67 during the growing season (April-September), the lowest average values occurring in September and highest in April. This work demonstrated that the southern part of the east-central Poland was the wettest in all the months of the growing season (Figure 1).

The driest months were the most common of all the classes to which months were assigned (on average, 2.9 times in 14 years). Extreme droughts occurred in May and June in the study area, being most frequently observed in Krzyżew and Uhnin. Extremely wet months were recorded most often in April but were less frequent than extreme droughts (on average, twice during 14 years). In turn, in Krzyżew and Nowy Lubliniec, April was extremely wet 3 times in the study period. July was the month which was most frequently very wet (on average, 0.9 times during 14 years). Months assigned to this class most often occurred in Cicibór Duży and Nowy Lubliniec and were the rarest in Marianów. Skowera and Puła 2004] analysed extreme pluviometric conditions in Poland in the spring from 1971 to 2000 and concluded that average Sielianinow's coefficients differed regionally throughout the country. According to 


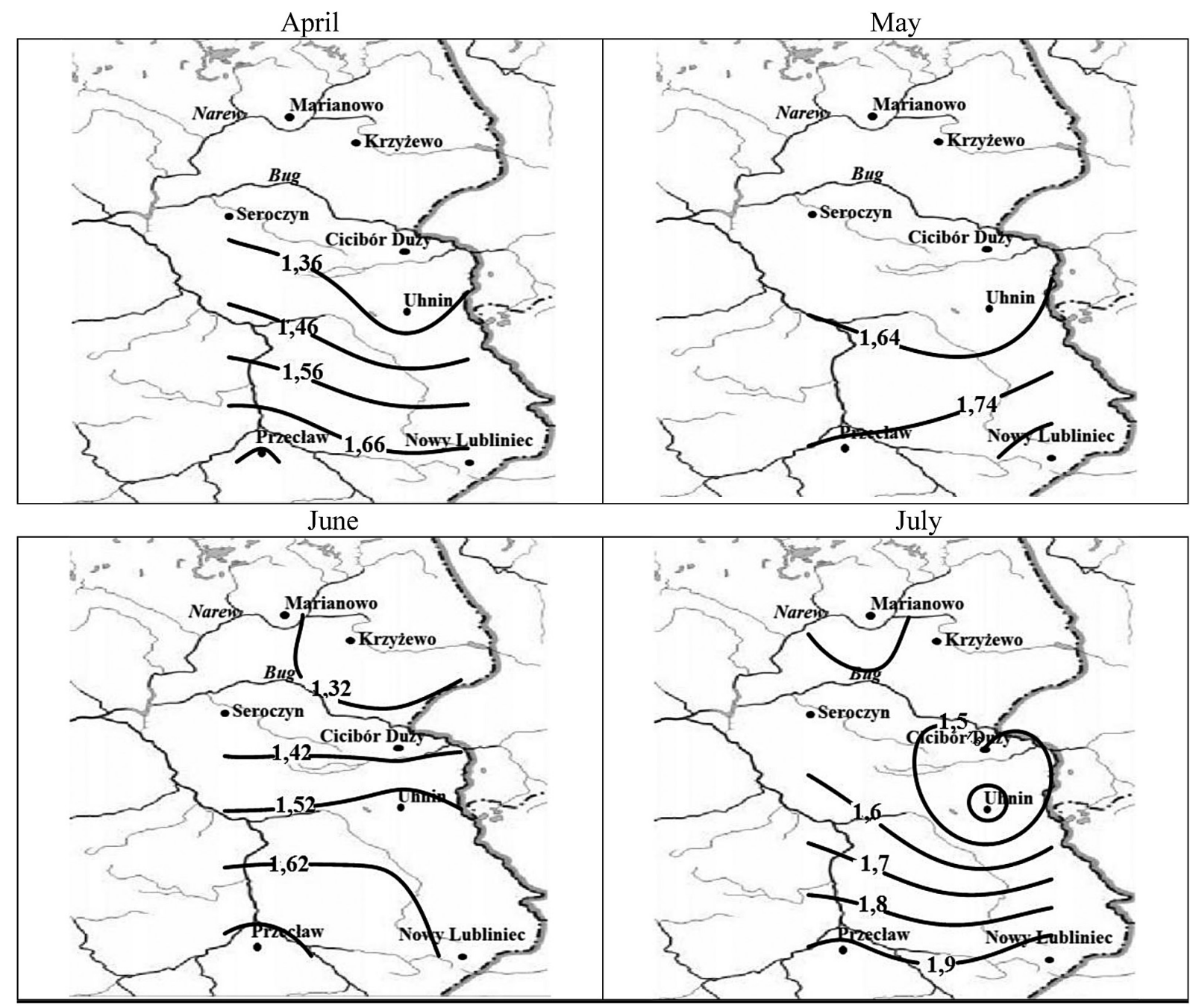

Figure 1. Spatial distribution of average values of Sielianinow's hydrothermal coetficient during the growing season (April-June) in east-central Poland in 2000-2013

the aforementioned authors, the south and north of Poland are the wettest regions in April whereas in May quite dry conditions prevail in most of the country. Quite wet and wet conditions were observed in southern Poland only. Throughout June optimum conditions predominate, quite wet and wet weather occurring in the north, south and north-east. Many authors point to an unfavourable effect of drought on plant growth and development due to decreased yields and poorer quality Radzka et al. 2010, Szwejkowski et al. 2008].

Values of the Sielianinow's hydrothermal coefficient in 38\% determined potato yields during the growing season (Table 1). The model revealed that potato yields were significantly affected by hydrothermal coefficient values in June only. The coefficients for April and May appeared in the model but their influence was not significant.

A more detailed description and Sielianinow's hydrothermal coefficient in individual stages on potato yields was obtained using multiple regression (Table 1 and 2).

Sielianinow's coefficient values in the second growth stage (June-July) significantly impact on early potato yield in east-central Poland. The relationship is parabolic in character. The maximum value of $450 \mathrm{dt}$ can be obtained when the Sielianinow's coefficient is 2.3. Adverse weather conditions affect the length of phonological stages and, sometimes, may extend the growing season, which, according to Jefferies and Lawson [1991], Sawicka [1991] as well as Sawicka and Krochmal-Marczak [2005], may directly influence potato yield and quality.

When the weather after potato planting is warm, plants establish more quickly. Plant water demand during this period is at its minimum. From emergence to flowering, plants require quite warm weather and moderate, evenly distributed precipitation. The greatest water demand 
Table 1. Regression equations for the relationship between early potato yields and Sielianinow's hydrothermal coefficient during the growing season

\begin{tabular}{|c|c|c|c|}
\hline \multicolumn{3}{|c|}{ Regression equations on Sielianinow's coefficient $\left(R^{2}=0.384\right)$} & $\mathrm{p}$ level \\
\hline variables in the model & regression coefficients & $\mathrm{t}$ test values & 0.00 \\
\hline Free term & 348.43 & 7.321 & 0.00 \\
\hline Sielianinow's coefficient in June & $-41.82^{*}$ & $2.784^{*}$ & 0.179 \\
\hline Sielianinow's coefficient in April & -21.53 & -1.401 & 0.318 \\
\hline Sielianinow's coefficient in May & 17.08 & 1.005 & \\
\hline
\end{tabular}

* - significant at $\mathrm{p} \leq 0 ., 05$.

Table 2. Components of orthogonal regression equation, t-Student values and graphs presenting early potato yields depending on Sielianinow's coefficient at two stages of growth and development

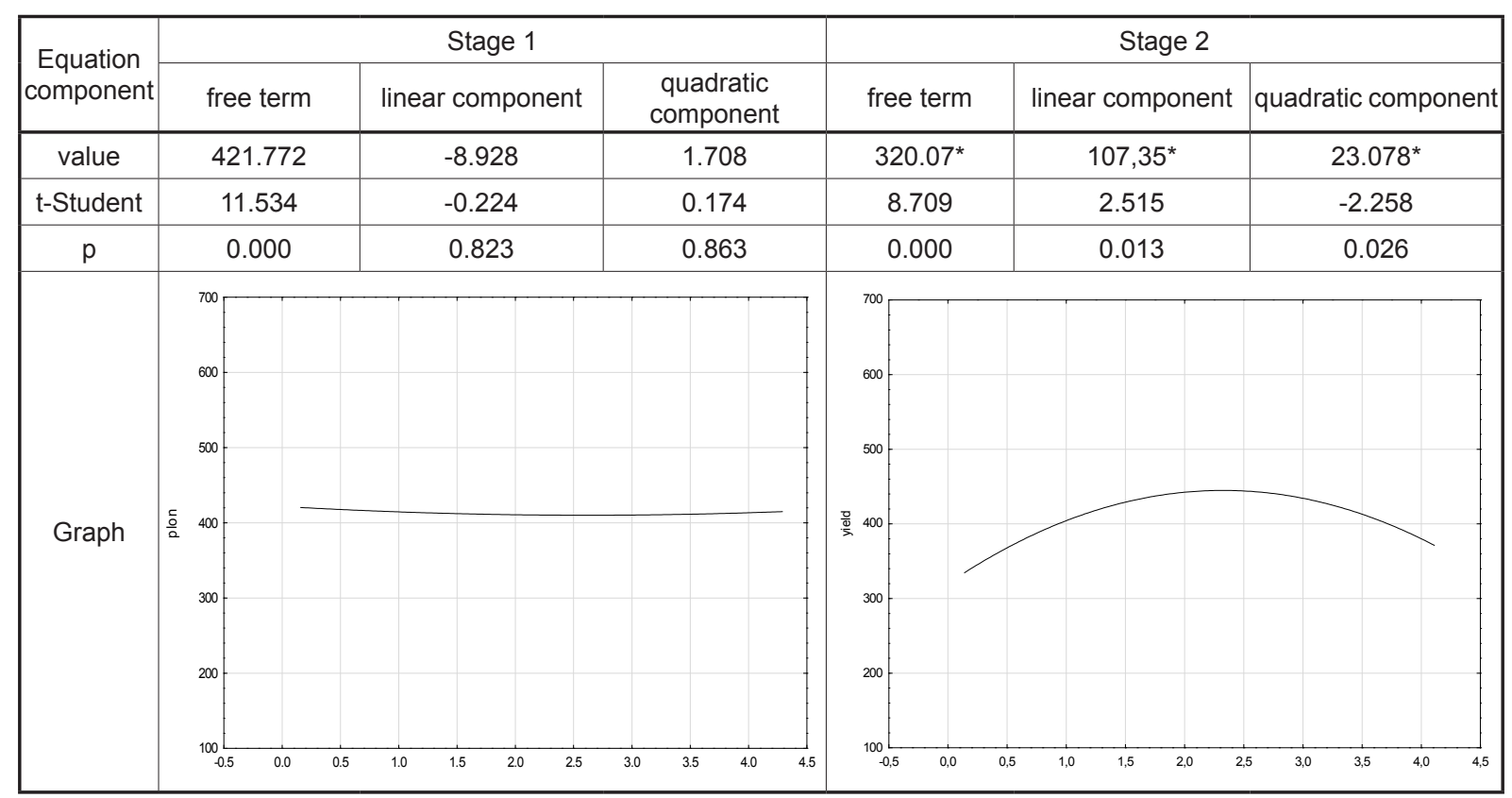

is at tuber set and intensive growth. At the final stage of tuber growth, warm, sunny weather with moderate and evenly distributed precipitation contributes to dry matter and starch accumulation in tubers. On the contrary, excessive precipitation during this period results in tuber infection with diseases and poorer storage quality in winter [Lutomirska 2005, 2006, 2008].

\section{CONCLUSIONS}

Average values of Sielianinow's hydrothermal coefficient in east-central Poland during the growing season of early potato ranged from 1.43 in April to 1.66 in May. The lowest $\mathrm{k}$ values in all the months of the growing season were obtained in the southern part of the study area.

The regression equation demonstrated that the yield was significantly affected by the Sielianinow's hydrothermal coefficient value in June.
The statistical methods applied in this work demonstrated that hydrothermal conditions exerted more impact on early potato yields particularly during the second part of the growing season. Maximum tuber yields of 460 and $450 \mathrm{dt}$ can be achieved when Sielianinow's coefficient is 2.3 respectively.

\section{REFERENCES}

1. Bartoszek K., Banasiewicz I., 2007. Agrometeorological characteristics of the vegetation period in 2005 against the background of the period of 1951-2005 in the Lublin region. Acta Agroph. 9(2), 275-283.

2. Bochenek W. 2012. Evaluation of precipitation at the IG\&SO pas research station in Szymbark during 40-year period (1971-2010)and its impact on the variability of ater runofffrom the Bystrzanka stream basin]. Woda Środ. Obsz. Wiej. 2(38), 29-44. 
3. Biniak M., Kostrzewa S., Żyromski A., 2007. Thermal and rainfall determinants of water demand in the Wrocław area as exemplified by medium-late potatoes. Zesz. Probl. Post. Nauk Rol. 519, 31-45.

4. Chmura K., 2001. Natural and agrotechnological determinants of potato cultivation in south-western Poland. Zesz. Nauk. AR in Wrocław, Dissertations 410.

5. Chotkowski J., Rembeza J., 2005. Consumer preferences and changes in potato consumption. Rocz. Nauk. Stow. Ekon. Rol. i Agrobiznesu 7(3), 42-49.

6. Dmowski Z., Nowak L., Chmura K., 2004. Reaction of varying in the length of a vegetation period to differentiated water-fertilization conditions. Biul. Inst. Hod.i Aklim. Rośl. No 232. 141-148.

7. Dzieżyc J., Nowak L., Panek K., 1987. Decade indices of precipitation requirements by crops in Poland. Zesz. Probl. Post. Nauk Roln., 314, 11-33.

8. Głuska A., 2000. Effect of cultivation technology on the quality of potato yield. Biul. IHAR 213, 173-178.

9. Hutorowicz H., Grabowski J., Olba-Zięty E., 2008. Frequency of occurrence of dry spells and droughts in two mesoregions of Masurian Lakeland. Acta Agroph. 12(3), 663-673.

10. Jakubowski T., 2007. Potato tuber cropping and susceptibility to mechanical damage related to hydrothermal coefficient. Inżynieria Rol. 8(96), 87-93.

11. Jefferies R.A., Lawson H.M., 1991: A key for the stages of development of potato (Solanum tuberosum). Ann. Appl. Biol., 119, 387-389.

12. Kalbarczyk R., 2003. Thermal and precipitation conditions in relation to the yielding of potato in Poland. Annales UMCS. Sectio E. Vol. 58. 35-44.

13. Kalbarczyk R., Kalbarczyk E., 2009. The requirements and deficiency in atmospheric precipitation in cultivated mid-late and late potato in Poland. Infrastructure and Ecology of Rural Areas, $\mathrm{Nr} 3$. 129-140.

14. Kapuściński J., Nowak R., 2003. The frequency of the occurrence of droughts and post-droughts periods in mid-west Poland on the example of Poznań, Wałcz and Wieluń. In: Management and conservation of the forest environment. Climate vs forest (Ed. Miler A.) Agricultural University in Poznań, 76-88.

15. Lutomirska B., 2005. The effect of temperature in mid-growing season on potato yield. Ziemniak Polski No 4. Bonin. 14-15.

16. Lutomirska B., 2006. Accelerating very early potato harvest. Ziemniak Polski No 1, 9-11.

17. Lutomirska B., 2008. The effects of cultivars and meteorological factors on variability of the potato phenophases. Ziemniak Polski No 247. Bonin. 119-134.
18. Mazurczyk W., Wierzbicka A., Wroniak J., 2009. Influence of optimisation of irrigation and nitrogen fertilisation on some growth parameters and yield of early potato variety. Infrastructure and Ecology of Rural Areas, No 3, 91-100.

19. Nowak L., 1989. Water requirements of rainfed tuber and root crops. Zesz. Probl. Post. Nauk Roln., $343,27-42$.

20. Nowak L., 2001. The effect of irrigation of medium-early potato in the Wrocław area. Fragm. Agron. 1, 68-75.

21. Nowak L., 2006. Water requirements of tuber and root crops. In: Plant Irrigation (Eds Kaczmarczyk S., Nowak L., PWRiL, Poznań, 368-372.

22. Radzka E., Jankowska J., Koc. G, Rak J., 2010. The effect of droughts on potato yields in east-central Poland. Fragm. Agron. 27(4), 111-118.

23. Rolbiecki S., Rzekanowski Cz., Rolbiecki R., 2009. Estimation of needs and results of irrigation of medium-early potato in the vicinity of Bydgoszcz in the years 2005-2007. Acta Agroph., 13(2), 463-472.

24. Sawicka B., 1991. A study of variation in selected characteristics and degeneration of different potato cultivars in the Biała Podlaska area. Publishing Centre of Agricultural University in Lublin, Rozpr. Nauk., 141, 1-75.

25. Sawicka B, Krochmal-Marczak B., 2005. Influence of agrometeorological factors on length of developmental phases of very early and early potato cultivars. Acta Agroph. 6(1), 225-236.

26. Skowera B., 2014. Changes of hydrothermal conditions in the Polish area (1971-2010). Fragm. Agron. 31(2), 74-87.

27. Skowera B., Puła J., 2004. Pluviometric extreme conditions in spring season in Poland in the years 1971-2000. Acta Agroph., 3(1), 171-177.

28. Szutkowska M., Lutomirska B., 2002. Influence of environmental conditions and agriculture factors on tubers infection with Streptomyces scabies. Biul. IHAR 221, 153-167.

29. Szwejkowski Z., Dragańska E, Suchecki S., 2008. Forecast of influence of expected global warming in year 2050 on crop yielding in north-eastern Poland. Acta Agroph. 12(3), 791-800.

30. Trętowski J., Wójcik A. R., 1991. Methodology of Agricultural Experiments. WSRP Siedlce, 79-94.

31. Ziernicka-Wojtaszek A., 2009. Verification of agro-climatic regionalisation types in Poland in the light of contemporary climate change. Acta Agroph., 13(3), 803-812.

32. Żarski J., 2011. Trends in changes of climatic indices for irrigation needs of plants in the region of Bydgoszcz. Infrastructure and Ecology of Rural Areas, 5, 29-37. 